J. Dairy Sci. 92:139-148

doi:10.3168/jds.2008-1477

(c) American Dairy Science Association, 2009.

\title{
Somatic cell count status across the dry period as a risk factor for the development of clinical mastitis in the subsequent lactation
}

\author{
J. C. F. Pantoja, C. Hulland, and P. L. Ruegg ${ }^{1}$ \\ Department of Dairy Science, University of Wisconsin, Madison 53706
}

\begin{abstract}
The objective of this study was to determine the risk of clinical mastitis in the first $120 \mathrm{~d}$ in lactation based on previous somatic cell count (SCC) history in a herd with a very low prevalence of contagious pathogens. A total of 218 cows from a university herd were enrolled at dry-off. Duplicate quarter milk samples were collected from all quarters at dry-off, postcalving ( 2 to $9 \mathrm{~d}$ in milk), and before treatment of all first cases of clinical mastitis that occurred during the first $120 \mathrm{~d}$ of the subsequent lactation. Quarter SCC statuses across the dry period were defined based on comparison of quarter SCC between the date of dry-off and the postcalving sampling periods. The relationship between the probability of developing clinical mastitis in the first $120 \mathrm{~d}$ of lactation and SCC status across the dry period and other explanatory variables was assessed using logistic regression. In the first $120 \mathrm{~d}$ postcalving, 68 first cases of clinical mastitis occurred in 47 cows. Of quarters that experienced a microbiologically positive clinical case, the same microorganism was never isolated from milk samples obtained at dry-off or consistently isolated from milk samples collected at all sampling periods. Coagulase negative staphylococci were the most prevalent pathogens isolated from subclinical intramammary infection, whereas gram-negative pathogens were the most common pathogen associated with clinical cases. Quarters that had at least 1 case of mastitis during the previous lactation were 4.2 times more likely to have a first case of clinical mastitis in the current lactation than quarters that did not have clinical mastitis in the previous lactation [odds ratio $(\mathrm{OR})=4.2(1.8,10.0)$ ]. Quarters of cows of greater than fourth parity were 4.2 times more likely to have a first case of clinical mastitis than quarters of cows of second parity [OR = $4.2(1.4,10.0)]$. Quarters with $\mathrm{SCC} \geq 200,000$ cells $/ \mathrm{mL}$ at dry-off and postcalving were 2.7 times more likely to experience a first case of mastitis than quarters with
\end{abstract}

Received June 23, 2008.

Accepted September 1, 2008.

${ }^{1}$ Corresponding author: plruegg@wisc.edu

SCC $<200,000$ cells $/ \mathrm{mL}$ at both periods $[\mathrm{OR}=2.7$ $(0.97,7.67)]$.

Key words: mastitis, dairy, dry period, somatic cell count

\section{INTRODUCTION}

The dry period has significant importance for mastitis epidemiology and the production of high quality milk (Dingwell et al., 2003). Intramammary infections that persist from the previous lactation and new infections that originate during the dry period can each contribute to the occurrence of subclinical and clinical mastitis in successive lactations (Green et al., 2007). Therefore, an understanding of the epidemiology and dynamics of IMI during the dry period is critical to improve milk quality and control mastitis (Green et al., 2005).

Approximately 10 to $17 \%$ of quarters may develop new IMI during the dry period, and most infections are caused by environmental organisms (Oliver, 1988; Dingwell et al., 2002; Green et al., 2005). When dry cow therapy (DCT) was not used, 50 to $63 \%$ of IMI acquired during the dry period were still present at calving (Neave et al., 1950; Oliver and Mitchell, 1983).

Although the occurrence of IMI is common during the dry period, only a few studies have investigated the relationship between dry period IMI and the risk of clinical mastitis in the subsequent lactation. Green et al. (2002) suggested that $38 \%$ of clinical mastitis cases $(\mathrm{n}=84)$ that occurred in the subsequent lactation were caused by pathogens that had been previously isolated from milk samples collected during the dry period or at dry-off. In a separate study, approximately $45 \%$ of clinical cases that developed in the first $100 \mathrm{~d}$ of the following lactation $(\mathrm{n}=85)$ were enterobacterial infections, of which $53 \%(\mathrm{n}=20)$ had been previously isolated during the dry period (Bradley and Green, 2000). Both of these studies were conducted in the United Kingdom using dairy herds $(\mathrm{n}=6)$ with bulk milk SCC $<250,000$ cells $/ \mathrm{mL}$, and neither herd used internal teat sealants during the dry period. In both studies, the detection limit for IMI was quite sensitive, as IMI were defined based on recovery of $100 \mathrm{cfu}$ per $\mathrm{mL}$ from single milk samples plated on blood agar or $10 \mathrm{cfu} /$ 
$\mathrm{mL}$ for milk samples plated on MacConkey agar. Extrapolation of these results to US dairy herds might be inappropriate because of differences in microbiological profiles of mastitis pathogens and the widespread usage of internal teat sealants. Quarters that received both intramammary DCT containing long-acting antibiotics and internal teat sealants were 30 to $59 \%$ less likely to develop a new IMI between dry-off and 1 to $3 \mathrm{~d}$ in milk (Godden et al., 2003; Cook et al., 2005) and 33\% less likely to experience clinical mastitis between dry-off and $60 \mathrm{~d}$ in milk than quarters treated with DCT alone (Godden et al., 2003).

Somatic cell count has been extensively used as a tool for monitoring mastitis in dairy herds (Dohoo and Leslie, 1991). Monthly SCC values that are routinely measured at cow level are useful measures of prevalence and incidence and are often used to monitor dynamics of IMI within herds (Ruegg, 2003). The composite milk SCC values obtained from DHI are often used to indicate udder health at herd and cow levels (Laevens et al., 1997). Farm managers often use SCC to identify cows requiring interventions such as culture, treatment, or removal from the herd (Cook et al., 2002). Monitoring of monthly SCC can be an effective way to improve milk quality and herds enrolled in a DHI testing program had reduced amounts of mastitis than herds that did not participate (Wilson et al., 1997).

Monitoring changes in monthly DHI SCC between test days has been recommended as a routine mastitis control strategy, but the relationship between these changes and quarter-level IMI and SCC has not been reported (Cook et al., 2002). The objective of this study was to determine the risk of developing clinical mastitis during the first $120 \mathrm{~d}$ in lactation based on previous SCC history in a herd with a very low prevalence of mastitis caused by contagious pathogens.

\section{MATERIALS AND METHODS}

\section{Enrolment of Animals and Sampling Strategy}

All multiparous cows from the University of Wisconsin's dairy herd that were dried off from August, 2005 to January, 2007 were enrolled at dry-off $(\mathrm{n}=218)$. The herd was composed of 285 lactating Holsteins that were milked twice daily, produced $33.2 \mathrm{~kg}$ of milk per cow per day, and had a bulk tank SCC of 240,000 cells/ $\mathrm{mL}$. Lactating cows were housed in tie stalls containing straw bedding, and dry cows were housed in freestalls containing sand. Cows routinely received core-antigen coliform vaccination as part of the herd health program.

Duplicate quarter milk samples were collected from all quarters at dry-off (before administration of DCT), postcalving $[$ median $=6$ DIM $(2$ to 9 DIM $)$, and before treatment of all first cases of clinical mastitis that occurred during the first $120 \mathrm{~d}$ of the subsequent lactation. Clinical mastitis was defined as abnormal milk with or without udder and systemic changes and was identified by trained farm personnel.

Groups of cows were routinely dried off once weekly, following the afternoon milking. After the farm's usual premilking routine (consisting of forestripping, predipping with a $0.5 \%$ iodine solution, and drying with a cloth towel), teat ends were thoroughly scrubbed with a $70 \%$ alcohol-soaked cotton pad and allowed to dry. Teats were then stripped and duplicate quarter foremilk samples (approximately $20 \mathrm{~mL}$ ) were aseptically collected in sterile plastic vials. Samples were immediately cooled and taken to the laboratory within $2 \mathrm{~h}$. After the final milking, all 4 quarters received intramammary DCT, which consisted of 1,000,000 units of procaine penicillin and $1 \mathrm{~g}$ of dihydrostreptomycin (QuarterMaster; Pfizer Animal Health, Kalamazoo, MI) followed by administration of an intramammary internal teat sealant that contained $4 \mathrm{~g}$ of bismuth subnitrate (Orbeseal; Pfizer Animal Health). Following treatment, all teats were dipped with a $1 \%$ iodine teat dip.

After the subsequent parturition, milk samples were collected before regular milking following the procedures described previously. During the first 120 d of lactation, duplicate samples were collected and frozen before treatment of clinical mastitis cases. Udder preparation, DCT, and collection of samples from clinical cases were carried out by trained farm personnel. Samples collected at dry-off and postcalving were always collected immediately before the afternoon milking by the first author.

\section{Bacteriology and SCC}

All milk samples were processed in the University of Wisconsin-Madison's Milk Quality Laboratory. When processing could not to be performed within $12 \mathrm{~h}$, samples were frozen for up to $1 \mathrm{wk}$. Microbiologic procedures were conducted according to the NMC (1999). In brief, $10 \mu \mathrm{L}$ of each milk sample was streaked onto one quarter of a blood agar plate. Plates were incubated at $37^{\circ} \mathrm{C}$ and read at 24 and $48 \mathrm{~h}$. An IMI was defined as the presence of 3 or more colonies of the same type. Milk samples that contained $\geq 3$ dissimilar colony types were considered contaminated. Initially, Staphylococcus aureus was differentiated from other staphylococci by means of mannitol and tube coagulase reactions. Streptococcus spp. were identified with the Christie, Atkins, Munch-Petersen test and esculin reaction. Gram-negative bacteria were identified using MacConkey agar, motility, indole, and ornithine reac- 
tions and growth on triple sugar iron slants. The final identification of microorganisms was performed using the appropriate API tests (API 20E, API 20Strep, and API Staph; bioMerieux-Vitek Inc., Hazelwood, MO). Only isolates yielding identification with API confidence levels greater than 0.90 were considered identified mastitis pathogens at species level. Otherwise, they were identified at genus level. Individual quarter SCC were determined using the Direct Cell Counter (DeLaval, Tumba, Sweden). Data from DHI were obtained electronically. Data pertaining to clinical mastitis during the previous lactation were obtained from the herd's management software and microbiological results were not available for those cases.

\section{Statistical Analysis}

Definitions Used for Analysis. Infection status was defined at the quarter level. A quarter was considered infected when the same mastitis pathogen was isolated from both duplicate milk samples obtained on each specific sampling date. Isolation of a mastitis pathogen from only one of the duplicate milk samples obtained on each sampling date was considered nonsignificant growth. Isolation of the same 2 pathogens from both duplicate milk samples was considered to be a mixed IMI. Milk samples were considered contaminated when $>2$ types of pathogens were recovered. When one of the duplicate samples was contaminated but no organisms were recovered from the other sample, the quarter was coded as no growth. Outcomes of quarters with nonsignificant growth were combined with no growth for analysis. When both duplicate milk samples were contaminated, the data were considered missing.

Quarter SCC status across the dry-period was defined based on comparison of quarter SCC between the date of dry-off and the postcalving sampling period using the following definitions: 1. estimated chronic infection (QECHRI): milk samples obtained from the same quarters that had SCC $\geq 200,000$ cells $/ \mathrm{mL}$ at the dryoff and postcalving sampling periods; 2 . estimated new infection (QENEWI): milk samples obtained from the same quarters that had a SCC $<200,000$ cells $/ \mathrm{mL}$ at the dry-off sampling period but had a SCC $\geq 200,000$ cells/mL at postcalving sampling period; 3. estimated cured infections (QECURI): milk samples that had a SCC $\geq 200,000$ cells $/ \mathrm{mL}$ at the dry-off sampling period and a SCC $<200,000$ cells/mL at postcalving sampling period; 4. estimated uninfected (QEUNIN): milk samples obtained from the same quarters that had SCC $<200,000$ cells $/ \mathrm{mL}$ at the dry-off and postcalving sampling periods. Somatic cell scores were calculated according to the formula SCS $=\log _{2}(\mathrm{SCC} / 100)+3$ (Shook, 1993).
Analysis at the Quarter Level. Initially, chisquare tests and logistic regression (Pagano and Gauvreau, 2000) were used to assess associations between the probability of developing clinical mastitis in the first $120 \mathrm{~d}$ of lactation (outcome variable) and individual explanatory variables. Univariate analyses were performed using PROC FREQ and PROC LOGISTIC (SAS Institute, 2008). Explanatory variables that were associated with the outcome variable $(P<0.25)$, as well as their interaction terms, were used to perform multivariate analysis. Final models were constructed according to forward and backward variable selection procedures and biological significance of variables. The model's goodness of fit was assessed using generalized chi-square tests (Littell et al., 2006).

The relationship between the probability of developing clinical mastitis in the first $120 \mathrm{~d}$ of lactation and quarter SCC status across the dry period and other explanatory variables (Table 1) was assessed using the following logistic regression mixed model (Littell et al., 2006):

$$
\begin{aligned}
\operatorname{Logit}\left(\pi_{\mathrm{ijklm}}\right) & =\alpha+\beta\left(\text { dry period length }_{\mathrm{i}}\right) \\
+\operatorname{SCCstatus~}_{\mathrm{j}}+ & \text { Prev lact } \text { mast }_{\mathrm{k}}+\text { Calv season }_{1} \\
& + \text { Parity }_{\mathrm{m}}+\delta_{\mathrm{i}},
\end{aligned}
$$

where $\pi$ is the probability of developing clinical mastitis in the first $120 \mathrm{~d}$ of the subsequent lactation (yes $=1$, no $=0), \alpha$ is the intercept, dry-period length $\mathrm{h}_{\mathrm{i}}$ is the length of the dry period (days) for the cow i, SCC status $_{j}$ is the SCC status ( $\mathrm{j}=$ QECHRI, QENEWI, QECURE, QEUNIN), Prev lact mast $_{k}$ is the occurrence of clinical mastitis in the previous lactation (yes $=1$, no $=0)$, Calv season $_{1}$ is the calving season ( 1 = fall, winter, spring, summer), Parity $y_{\mathrm{m}}$ is the parity status $(\mathrm{m}=2,3,4$ and $>4)$, and $\delta_{\mathrm{i}}$ is a random term relative to the effect of cow i, used to model the covariance between observations on each quarter within each cow (Barkema et al., 1997). Collinearity was observed between the variables SCC status across the dry period and the occurrence of clinical mastitis in the previous lactation due to the strong association found between them $(P<0.01)$. As a result, either variable ordered first in a model containing both variables captured the effect of the following, which became no longer statistically significant (as assessed by using type I analysis of effects). Therefore, model 2 was created so that these variables were not present simultaneously in the same model:

$$
\begin{aligned}
& \operatorname{Logit}\left(\pi_{\mathrm{ijkl}}\right)=\alpha+\beta\left(\text { dry period length } \mathrm{i}_{\mathrm{i}}\right) \\
& + \text { SCCstatus }_{\mathrm{j}}+\text { Calv season }_{\mathrm{k}}+\text { Parity }_{\mathrm{l}}+\delta_{\mathrm{i}} \text {. }
\end{aligned}
$$


Table 1. Description of variables

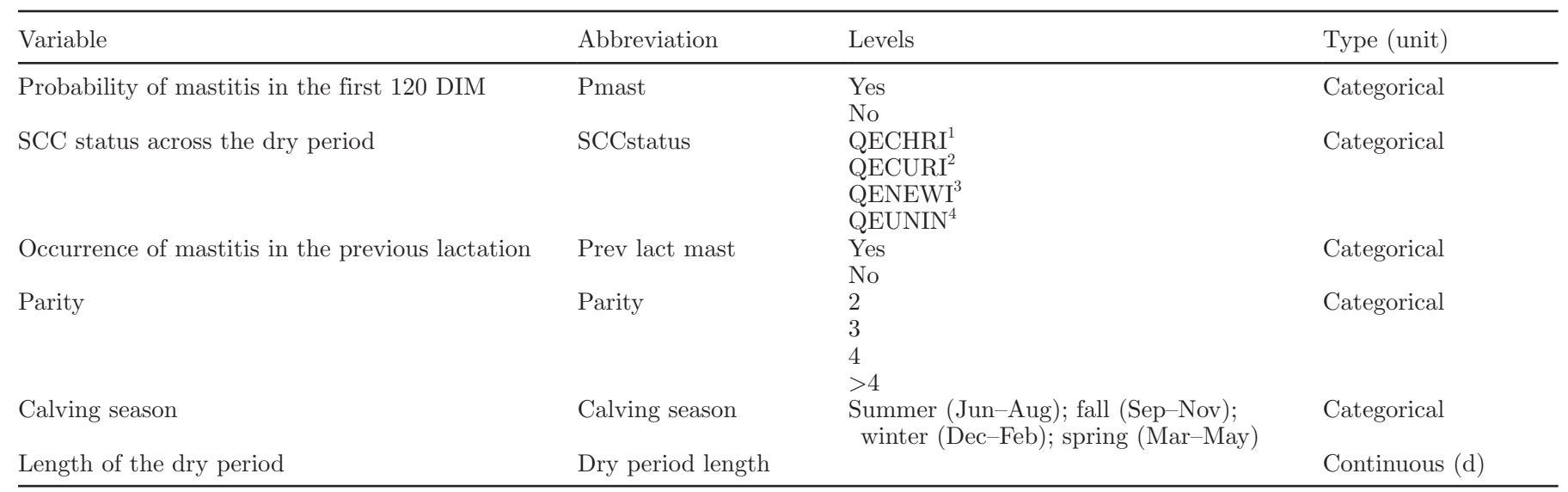

${ }^{1}$ Quarters with SCC $\geq 200,000$ cells $/ \mathrm{mL}$ at dry-off and postcalving.

${ }^{2}$ Quarters with SCC $\geq 200,000$ cells/mL at dry-off and $<200,000$ cells/mL at postcalving.

${ }^{3}$ Quarters with SCC $<200,000$ cells $/ \mathrm{mL}$ at dry-off and $\geq 200,000$ cells $/ \mathrm{mL}$ at postcalving.

${ }^{4}$ Quarters with SCC $<200,000$ cells $/ \mathrm{mL}$ at dry-off and postcalving.

Logistic regression with a random effect was performed using PROC GLIMMIX (SAS Institute, 2008). Quarters that developed clinical cases before the postcalving samples were collected $(\mathrm{n}=15)$ were removed from the analysis because SCC from postcalving milk samples was used to create one of the explanatory variables (SCC status). To address potential concerns about introducing bias by exclusion of these data, available SCC data from the dry-off milk samples (n $=14$ of 15 cases) were used to simulate all possible SCC statuses across the dry-period. Analyses using the simulated data indicated that the exclusion of the cases did not change the outcome, and the cases were therefore excluded in the final analysis.

The PROC LIFETEST (SAS Institute, 2008) was used to perform survival analysis of quarters stratified on SCC status (QECHRI, QENEWI, QECURI, QEU$\mathrm{NI})$. The first 120 DIM were used as the time period in the survival analysis. The event was defined as the occurrence of a first clinical case, and quarters that did not develop clinical mastitis within $120 \mathrm{~d}$ were censored at the end of the interval. Kaplan-Meier survival curves were produced to calculate the cumulative incidence of clinical mastitis and probability of survival for each stratum of SCC status. The null hypothesis of no differences in the survivor functions of the strata (SCC status) was evaluated using log-rank and Wilcoxon tests (Pagano and Gauvreau, 2000). The tests differ in their sensitivity to various kinds of departures from that hypothesis. The Wilcoxon test is less sensitive than log-rank to differences in the groups that occur at later points in time. Chi-square tests (Pagano and Gauvreau, 2000) were used to assess the association between clinical cases that occurred between calving and the postcalving sampling day $(\mathrm{n}=15)$ and season (summer, fall, winter, and spring) and days in milk (0, $1,2,3$, and 4 ). The level of statistical significance was set at 0.05 for all analyses.

\section{RESULTS}

Of animals initially enrolled ( $\mathrm{n}=218$ cows; 861 quarters), complete data were obtained from 205 cows (809 quarters), 11 cows (44 quarters) were removed from the herd before completion of the 120-d follow-up period and 2 cows (8 quarters) died. One of the 2 cows died due to toxic mastitis at calving. With the exception of milk samples obtained from cows with clinical cases of mastitis, most milk samples were microbiologically negative or contained nonsignificant quantities of bacteria and few samples were contaminated (Table 2).

\section{Population Characteristics}

Most enrolled cows were of second parity at calving and a similar proportion of cows calved in the winter and fall (Table 3). The dry period had a mean length of $68 \mathrm{~d}$, which was close to the industry standards. The average somatic cell score in the previous lactation was $2.6(\mathrm{SD}=1.3)$, and milk yields for the last DHI test in the previous lactation and first DHI test in the current lactation were $24.7 \mathrm{~kg}$ (5.8) and $36.8 \mathrm{~kg}$ (8.8), respectively (Table 3 ).

\section{Prevalence of IMI Across the Dry Period}

The prevalence of IMI was $12.8 \%(\mathrm{n}=102)$ at dry-off and $6.9 \%(\mathrm{n}=55)$ at postcalving. The most prevalent microorganisms isolated from milk samples collected at those periods were CNS, which caused 63 (dry-off) 
Table 2. Proportion of outcomes of microbiological analysis of duplicate milk samples collected at dry-off, postcalving, first DHI test, and before treatment of clinical cases

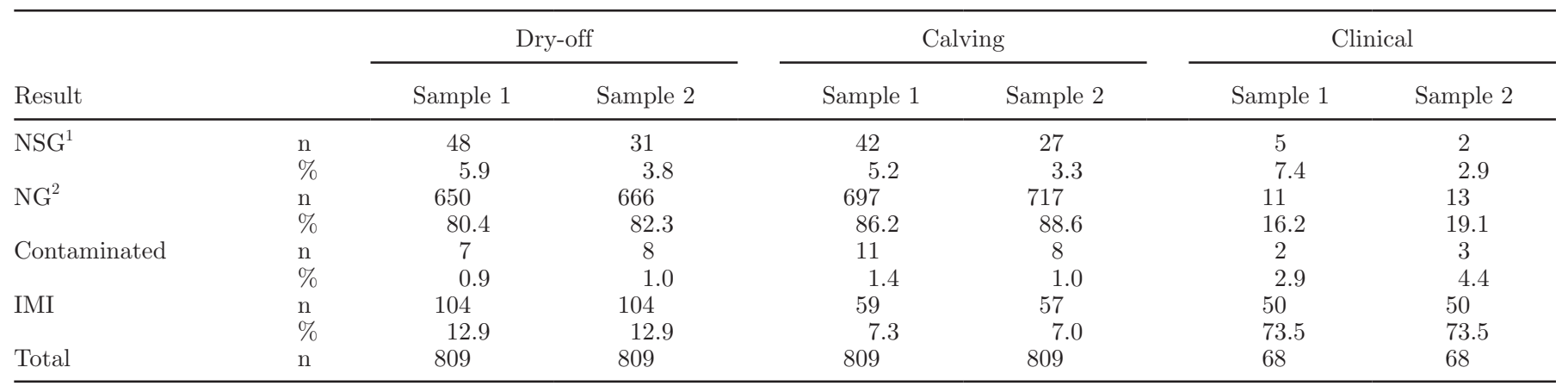

${ }^{1}$ Nonsignificant growth of bacteria.

${ }^{2}$ No growth of bacteria.

and $44 \%$ (postcalving) of all IMI (Table 4). Of quarters from which an IMI was diagnosed at dry-off $(\mathrm{n}=102)$, $91(90.1 \%)$ did not have an IMI present at postcalving (cured IMI). Forty-five quarters $(6.5 \%)$ that did not have an IMI present at dry-off had an IMI detect at postcalving (new IMI), and 10 quarters $(9.9 \%)$ had an IMI present at dry-off and postcalving (chronic IMI).

\section{Occurrence of Clinical Mastitis and Microbiological Results}

Sixty-eight first cases of clinical mastitis occurred in 47 cows, between calving (d 0) and d 120 postcalving (1.4 quarters per cow). The median DIM at occurrence of the first clinical case was 39.5. There was no significant difference among the proportion of clinical cases that occurred during summer (34.3\%), fall (26.8\%), winter $(22.3 \%)$, and spring $(16.4 \% ; P=0.20)$. Most clinical mastitis cases $(23.3 \%)$ occurred in quarters from cows of parity 5 or greater, as compared with quarters from cows of parities 2,3 , and $4(P<0.01$, Table 5$)$.
Month of calving was associated with the occurrence of a clinical case $(P=0.01$, Table 5$)$.

Of the 68 cases of clinical mastitis, 15 (22\%) occurred in 9 cows between $\mathrm{d} 0$ and 4 (1.7 quarters per cow) before postcalving milk samples could be obtained. As previously noted, data from these 15 cases were excluded from the initial statistical analysis that required the postcalving SCC to define SCC status. The distribution of cases with missing SCC data was as follows: day of calving $(\mathrm{n}=3)$; d $1(\mathrm{n}=3)$; d $2(\mathrm{n}=7)$; d $3(\mathrm{n}=1)$; and $\mathrm{d} 4(\mathrm{n}=1)$. Most postparturient cases occurred in summer $(60 \%)$, in contrast to fall $(13.3 \%)$, winter $(20.0 \%)$ or spring $6.7 \% ; P<0.01)$. The SCC of quarter milk samples obtained at dry-off exceeded 200,000 cells/mL for all postparturient cases that occurred on $\mathrm{d}$ 0 and $1(\mathrm{n}=6)$, although no pathogens were recovered at dry-off. Of postparturient cases that occurred on d 2 to $4(\mathrm{n}=9), 7$ quarters had previous $\mathrm{SCC} \geq 200,000$ cells/mL from samples collected at dry-off. Staphylococcus caprae and Aerococcus viridians were previously recovered from 2 of these 7 quarters at dry-off, whereas

Table 3. Population characteristics of enrolled cows

\begin{tabular}{|c|c|c|c|c|c|c|}
\hline Variable & $\mathrm{n}$ & $\%$ & Mean & $\mathrm{SD}$ & Minimum & Maximum \\
\hline 2 & 125 & 60.9 & & & & \\
\hline 3 & 40 & 19.5 & & & & \\
\hline$>4$ & 21 & 10.2 & & & & \\
\hline \multicolumn{7}{|l|}{ Calving season } \\
\hline Summer & 38 & 18.6 & & & & \\
\hline Spring & 27 & 13.2 & & & & \\
\hline Length of dry period ${ }^{1}$ & 205 & & 68.0 & 19.2 & 8 & 199 \\
\hline Previous SCS ${ }^{2}$ & 205 & & 2.6 & 1.3 & 0.3 & 5.9 \\
\hline Milk yield at last DHIA test (kg) & 205 & & 24.7 & 5.8 & 11.8 & 42.3 \\
\hline Milk yield at first DHIA test $(\mathrm{kg})$ & 205 & & 36.8 & 8.8 & 16.4 & 63.2 \\
\hline
\end{tabular}

${ }^{1}$ Number of days between dry-off and calving.

${ }^{2}$ Previous lactation average somatic cell score. 
Table 4. Microbiological results from all sampling periods

\begin{tabular}{|c|c|c|c|}
\hline Microbiological results & \multicolumn{3}{|c|}{ Sampling period } \\
\hline Gram-negative - subtotal & $2(0.25)$ & $7(0.86)$ & $19(27.9)$ \\
\hline Enterobacter sakazaki & & $2(0.25)$ & $1(1.47)$ \\
\hline Escherichia coli & $2(0.25)$ & $2(0.25)$ & $11(16.18)$ \\
\hline Pseudomonas spp. & & & $1(1.47)$ \\
\hline Klebsiella terrigena & & & $1(1.47)$ \\
\hline Gram-positive subtotal & $97(12.1)$ & $44(5.4)$ & $28(41.1)$ \\
\hline Arcanobacter pyogenes & $3(0.37)$ & (ס) & $20(1+1)$ \\
\hline Corynebacterium bovis & $6(0.75)$ & $4(0.5)$ & $1(1.47)$ \\
\hline Corynebacterium renale & $1(0.12)$ & & \\
\hline CNS & $64(8.0)$ & $24(3.0)$ & $6(8.8)$ \\
\hline Streptococcus uberis & $3(0.37)$ & $8(0.99)$ & $6(8.82)$ \\
\hline Enterococcus spp. & $3(0.37)$ & $4(0.5)$ & \\
\hline Aerococcus viridians & $5(0.62)$ & $2(0.25)$ & $2(2.94)$ \\
\hline Micrococcus spp. & $3(0.37)$ & & \\
\hline Bacillus spp. & & $1(0.12)$ & $2(2.94)$ \\
\hline Others - subtotal & $3(0.37)$ & $4(0.49)$ & $3(4.41)$ \\
\hline Yeast & & $1(0.12)$ & $2(2.94)$ \\
\hline Mixed infection & $3(0.37)$ & $3(0.37)$ & $1(1.47)$ \\
\hline Total IMI & $102(12.8)$ & $55(6.90)$ & $50(73.6)$ \\
\hline No infection & $704(88.1)$ & $753(93.1)$ & $18(26.5)$ \\
\hline Total quarter milk samples ${ }^{2}$ & 804 & 808 & 68 \\
\hline
\end{tabular}

${ }^{1}$ API results obtained with $<90 \%$ of confidence at species level.

${ }^{2}$ Total quarter milk samples that were included in the statistical analysis for microbiology.

microbiological results at calving were Staphylococcus epidermidis and NG, respectively.

Postcalving milk samples were collected for 53 cases of clinical mastitis (78\%) that occurred in 38 cows between 2 and 120 DIM. The median DIM at the occurrence of the first clinical case was 53 . Of the 53 clinical cases with complete microbiological data, 2 quarters $(3.8 \%)$ had the same species of pathogen isolated from clinical and postcalving milk samples (1 quarter had Staphylococcus simulans and the other had Klebsiella pneumoniae isolated from both periods). None of the quarters that experienced a microbiologically positive clinical case had previously had the same microorganism isolated from milk samples obtained at dry-off. None of the quarters that experienced a microbiologically positive clinical case had the same pathogen consistently isolated from milk samples collected at all sampling periods.

The occurrence of clinical mastitis in the previous lactation was strongly associated with SCC status across the dry period $(P<0.01)$. During the previous lactation, 78 (9.6\% of the quarters at risk) cases of clinical mastitis occurred in 54 cows $(1.4$ cases per cow). Of quarters with SCC status defined as QECHRI,
$30 \%$ had experienced a case of clinical mastitis case in the previous lactation, in contrast to quarters with status defined as QECURI (11.8\%), QENEWI (10.1\%), or QEUNIN (5\%).

The microbiological profile of the pathogens isolated from clinical cases was remarkably different from the profile of pathogens isolated from subclinical cases determined during the previous sampling periods (Table 4). Coagulase-negative staphylococci were the most prevalent pathogens isolated from subclinical IMI, whereas gram-negative pathogens were the most common outcome of clinical cases (Table 4). Staphylococcus aureus $(\mathrm{n}=4)$ was isolated only from 4 clinical cases that occurred during the last third of the study.

\section{Risk of Clinical Mastitis in First 120 DIM of the Subsequent Lactation}

When the occurrence of clinical mastitis in the previous lactation was included in the model (model 1, Table 6 ), it was strongly associated with the risk of clinical mastitis in the first 120 DIM $(P<0.01)$. Quarters that had experienced at least 1 case of clinical mastitis during the previous lactation were 4.2 times more likely to 
Table 5. Univariate investigation of risk factors for the development of a first case of clinical mastitis in the first $120 \mathrm{~d}$ of the subsequent lactation

\begin{tabular}{|c|c|c|c|}
\hline Risk factor & Quarters, n & $\begin{array}{c}\text { Clinical }^{1} \\
\text { mastitis, n }(\%)\end{array}$ & $P$-value ${ }^{2}$ \\
\hline Parity & & & $<0.01$ \\
\hline 2 & 494 & $24(4.9)$ & \\
\hline 3 & 159 & $20(12.6)$ & \\
\hline 4 & 74 & $4(5.4)$ & \\
\hline$>4$ & 86 & $20(23.3)$ & \\
\hline Cases last lactation $^{3}$ & & & $<0.01$ \\
\hline No & 735 & $50(6.8)$ & \\
\hline Yes & 78 & $18(23.1)$ & \\
\hline Calving season & & & 0.01 \\
\hline Summer & 151 & $21(13.9)$ & \\
\hline Fall & 266 & $23(8.6)$ & \\
\hline Winter & 288 & $13(4.5)$ & \\
\hline Spring & 108 & $11(10.2)$ & \\
\hline SCC status & & & $<0.01$ \\
\hline QECHRI $^{4}$ & 67 & $14(20.9)$ & \\
\hline QECURI $^{5}$ & 222 & $14(6.3)$ & \\
\hline QENEWI $^{6}$ & 79 & $3(3.8)$ & \\
\hline QEUNIN $^{7}$ & 420 & $21(5.0)$ & \\
\hline
\end{tabular}

${ }^{1}$ Quarter clinical cases in the first $120 \mathrm{~d}$ in milk of the subsequent lactation.

${ }^{2}$ Fisher's exact test.

${ }^{3}$ Occurrence of at least 1 clinical case during the previous lactation.

${ }^{4}$ Quarters with SCC $\geq 200,000$ cells $/ \mathrm{mL}$ at dry-off and postcalving.

${ }^{5}$ Quarters with SCC $\geq 200,000$ cells $/ \mathrm{mL}$ at dry-off and $<200,000$ cells $/ \mathrm{mL}$ at postcalving.

${ }^{6}$ Quarters with SCC $<200,000$ cells $/ \mathrm{mL}$ at dry-off and $\geq 200,000$ cells $/ \mathrm{mL}$ at postcalving.

${ }^{7}$ Quarters with SCC $<200,000$ cells/mL at dry-off and calving.

have a first case of clinical mastitis than quarters that did not have clinical mastitis in the previous lactation [odds ratio $(\mathbf{O R})=4.2(1.8,10.0)]$. Quarters from cows of greater than fourth parity were 4.2 times more likely to have a first case of clinical mastitis than quarters from cows of second parity $[\mathrm{OR}=4.2(1.4,10.0)]$. When the occurrence of clinical mastitis in the previous lactation was not included in the model, SCC status across the dry period had a tendency to be associated with the risk of clinical mastitis (for cases from which complete sampling data was collected) in the first 120 DIM (model 2, $P=0.09$, Table 6). Quarters defined as QECHRI were 2.7 times more likely to experience a first case of mastitis than quarters defined as QEUNIN [OR $=2.72$ (0.97 to 7.67)]. Quarters from cows of greater than fourth parity were 4.2 times more likely to have a first case of clinical mastitis than quarters from cows of second parity $[\mathrm{OR}=4.2(1.43,12.50)]$. Calving season and length of the dry period were not significantly associated with the probability of a quarter developing clinical mastitis in the first 120 DIM and were therefore excluded from the models.

Survival Analysis. Of the 67 quarters defined as QECHRI, 14 (21\%) developed a case of clinical mastitis in the first $120 \mathrm{DIM}$, in contrast to $21(5 \%)$ of the 420 quarters defined as QEUNIN, $3(3.8 \%)$ of the 79 quarters defined as QENEWI and $14(6.3 \%)$ of the 222 quarters defined as QECURI. The strata had different curves (Figure 1, Log-rank and Wilcoxon tests, $P<$ $0.01)$.

\section{DISCUSSION}

The objective of the present study was to determine the risk of clinical mastitis in the first 120 DIM based on previous SCC information from milk samples obtained across the dry period. We provide evidence that quarters with SCC $\geq 200,000$ cells/mL from dry-off and postcalving milk samples (QECHRI) had an increased risk of developing clinical mastitis in the first 120 DIM of the subsequent lactation than quarters with SCC $<200,000$ cells $/ \mathrm{mL}$ at both periods (QEUNIN). In addition, quarters classified as QECHRI were more susceptible to the development of clinical mastitis even when no pathogens were isolated or the isolation of the same pathogen species from consecutive sampling across the dry period was not consistent. The greater prevalence of clinical mastitis in the previous lactation (30\% of the quarters classified as QECHRI as opposed to $5 \%$ of quarters classified as QEUNIN) most likely contributed to the increased susceptibility to mastitis in the subsequent lactation. The occurrence of mastitis in the previous lactation was a risk factor for the development of clinical mastitis in early lactation and was also strongly associated with SCC status across the dry period. These variables can be considered sur- 
Table 6. Results of the 2 final logistic regression mixed models for the analysis at quarter level in which the response variable was the probability of clinical mastitis in the first 120 DIM

\begin{tabular}{|c|c|c|c|c|c|c|}
\hline \multirow[b]{2}{*}{ Explanatory variable } & \multirow[b]{2}{*}{ Coefficient } & \multirow[b]{2}{*}{$\mathrm{SE}$} & \multirow[b]{2}{*}{$P$-value } & \multirow[b]{2}{*}{ Odds ratio $^{1}$} & \multicolumn{2}{|c|}{$95 \% \mathrm{CI}^{2}$} \\
\hline & & & & & LCL & UCL \\
\hline \multicolumn{7}{|l|}{ Model 1} \\
\hline Intercept & -0.51 & 0.67 & & & & \\
\hline Parity & & & 0.03 & & & \\
\hline 2 & -1.42 & 0.55 & & 0.24 & 0.10 & 0.70 \\
\hline 3 & -0.70 & 0.57 & & 0.43 & 0.15 & 1.26 \\
\hline \multicolumn{3}{|l|}{ Prev lact mast } & $<0.01$ & & & \\
\hline No & -1.44 & 0.42 & & 0.24 & 0.10 & 0.55 \\
\hline Yes & Reference & & & & & \\
\hline \multicolumn{3}{|l|}{ SCCstatus } & 0.39 & & & \\
\hline $\mathrm{QECHRI}^{3}$ & 1.00 & 0.53 & & 1.72 & 0.57 & 5.16 \\
\hline QECURI $^{4}$ & -0.06 & 0.45 & & 0.78 & 0.32 & 1.95 \\
\hline QENEWI $^{5}$ & -0.30 & 0.67 & & 0.58 & 0.15 & 2.30 \\
\hline 2 & -1.42 & 0.54 & & 0.24 & 0.08 & 0.70 \\
\hline 3 & -0.85 & 0.55 & & 0.43 & 0.15 & 1.26 \\
\hline 4 & -2.00 & 0.87 & & 0.14 & 0.03 & 0.76 \\
\hline$>4$ & Reference & & & & & \\
\hline \multicolumn{3}{|l|}{ SCCstatus } & 0.09 & & & \\
\hline $\mathrm{QECHRI}^{3}$ & 1.00 & 0.53 & & 2.72 & 0.97 & 7.67 \\
\hline QECURI $^{4}$ & -0.06 & 0.45 & & 0.94 & 0.39 & 2.28 \\
\hline QENEWI $^{5}$ & -0.30 & 0.67 & & 0.74 & 0.20 & 2.77 \\
\hline QEUNIN $^{6}$ & Reference & & & & & \\
\hline$\delta$ (random term) & 1.22 & 0.42 & & & & \\
\hline
\end{tabular}

${ }^{1}$ Odds of developing clinical mastitis in the first 120 DIM.

${ }^{2}$ Confidence interval for odds ratio (lower and upper confidence limits).

${ }^{3}$ Quarters with $\mathrm{SCC} \geq 200,000$ cells/mL at dry-off and postcalving.

${ }^{4}$ Quarters with SCC $\geq 200,000$ cells $/ \mathrm{mL}$ at dry-off and $<200,000$ cells $/ \mathrm{mL}$ at postcalving.

${ }^{5}$ Quarters with SCC $<200,000$ cells $/ \mathrm{mL}$ at dry-off and $\geq 200,000$ cells $/ \mathrm{mL}$ at postcalving.

${ }^{6}$ Quarters with SCC $<200,000$ cells/mL at dry-off and calving.

rogate variables because they measure the same disease (mastitis) in 2 different states (clinical and subclinical). Therefore, we did not include both of the variables in the same final model.

Increasing parity has been reported to be a risk factor for new dry period infections, suggesting that anatomical or intramammary defense mechanisms of cows may deteriorate with age (Dingwell et al., 2004). Thus, previous exposure or infection with mastitis pathogens, or decreased patency of the teat sphincter may contribute to increased susceptibility. In a previous study in which most of the new IMI acquired during the dry period were caused by environmental organisms, the distribution of IMI during the dry period was $14 \%$ for second parity and $31 \%$ for both third and fourth or greater parity cows (Dingwell et al., 2004). In agreement with Dingwell et al. (2004), Green et al. (2002), and Sanford et al. (2006), parity was a risk factor for the development of clinical mastitis in the subsequent lactation. Other possible risk factors such as length of the dry period and calving season were not associated with the risk of clinical mastitis in this study, when adjusting for the other variables included in the models.

In recent years, the overall prevalence of IMI has decreased and there has been an increase in the proportion of infections caused by environmental organisms such as Escherichia coli and Streptococcus species, as compared with a decrease in IMI caused by contagious pathogens such as Staphylococcus aureus (Makovec and Ruegg, 2003; Green et al., 2005). In this study, CNS were the most prevalent pathogens isolated from subclinical IMI, and gram-negative pathogens were rarely isolated. As noted previously (Hoe and Ruegg, 2005), gram-negative pathogens were the most commonly recovered pathogen in milk samples obtained from clinical cases of mastitis. In several other studies, CNS have been the most prevalent pathogens isolated from milk samples collected at dry-off and postcalving (Oliver and Mitchell, 1983; Hogan et al., 1989; Cook et al., 2005). Although the data used in this study were obtained 
from a single university research herd, the prevalence of IMI may be representative of a broader population of herds because the rates were very similar to prevalence reported for 3 commercial herds in Wisconsin (Cook et al., 2005). The prevalence of subclinical IMI at dry-off $(12.8 \%)$ and the proportion of IMI caused by CNS (8\%) reported in this study are almost identical to the prevalence of $12.4 \%$ (subclinical IMI at dry-off) and $8.4 \%$ (IMI caused by CNS) previously reported by Cook et al. (2005).

In the present study, there was no evidence that pathogens causing IMI at dry-off survived through the dry period and caused clinical mastitis in the first 120 $\mathrm{d}$ of the subsequent lactation. None of the quarters that experienced a microbiologically positive clinical case had the same microorganism previously isolated from milk samples obtained at dry-off. Likewise, quarters that experienced a microbiologically positive clinical case never had the same pathogen consistently isolated from milk samples collected at both screening periods (dry-off and postcalving). Many of the IMI were attributable to minor pathogens that are have been previously noted to frequently experience spontaneous cures (Seymour et al., 1989). Of the 53 clinical mastitis cases that occurred between 2 (after the postcalving sampling day) and 120 DIM, 51 (96\%) appeared to be new cases originated during lactation. Only $3.8 \%(\mathrm{n}=$ 2) had the same pathogen isolated from postcalving samples, which indicates that these clinical cases might have originated during the dry period or in the first days of lactation. Of the 15 clinical mastitis cases that occurred between calving and the actual postcalving sampling day (0 to 4 DIM), only 3 quarters had an IMI diagnosed from the sample collected at dry-off, from which a different pathogen from that causing the clinical case was isolated. Due to the occurrence immediately postpartum, it might be hypothesized that they were acquired during the dry period or in the immediate postpartum period. The recurrence of mastitis in the same quarter but caused by different pathogens may be an indication that teat structure is an important risk factor for mastitis.

Our results contrast with several previous studies but important differences among herds and study methodologies should be noted. Data from 6 herds in the United Kingdom with bulk milk SCC $<250,000$ cells/mL and a prevalence of approximately $6 \%$ of clinical mastitis caused by coagulase-positive staphylococci suggested that approximately $38 \%(\mathrm{n}=32)$ of 84 quarter clinical mastitis cases that occurred in the subsequent lactation had the same species of pathogen previously isolated from at least 1 of 2 samples collected during the dry period or from samples collected at drying off (Green et al., 2002). In one study (also from 6 herds in the United

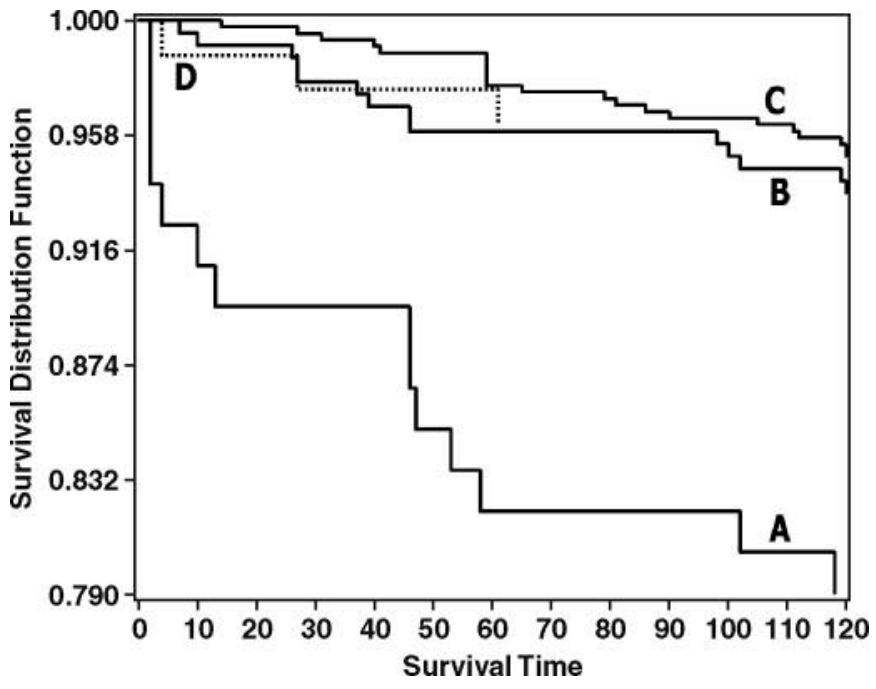

Figure 1. Kaplan-Meier survival curves. The survival function is for the first case of clinical mastitis occurring in the first $120 \mathrm{~d}$ of the subsequent lactation. A) quarters with SCC $\geq 200,000$ cells/mL at dryoff and calving (QECHRI, $\mathrm{n}=67$ ); B) quarters with $\mathrm{SCC} \geq 200,000$ cells/mL at dry-off and SCC $<200,000$ cells/mL at calving (QECURI, $\mathrm{n}=222)$; C) quarters with SCC $<200,000$ cells $/ \mathrm{mL}$ at dry-off and calving (QEUNIN, $\mathrm{n}=420$ ); and D) quarters with SCC $<200,000$ cells/mL at dry-off and SCC $\geq 200,000$ cells/mL at calving (QENEWI, $\mathrm{n}=79)$.

Kingdom with bulk milk SCC $<250,000$ cells/mL), approximately $45 \%(\mathrm{n}=38)$ of quarter clinical cases $(\mathrm{n}$ $=85$ ) that developed in the first $100 \mathrm{~d}$ of the following lactation were enterobacterial infections, $53 \%(\mathrm{n}=20)$ of which had been previously isolated during the dry period. In addition, $71 \%$ of the 38 clinical cases had the same species of pathogen previously isolated from samples collected at dry-off, during the dry period, or postcalving (Bradley and Green, 2000). However, detection limits of $100 \mathrm{cfu} / \mathrm{mL}$ for single milk samples plated onto blood agar and $10 \mathrm{cfu} / \mathrm{mL}$ for samples plated onto MacConkey agar were used to define an IMI in both studies. Thus, for dairy herds to which results of this study can be extrapolated, the dynamics of IMI in the dry period and their impact on the incidence of clinical mastitis in the subsequent lactation appear to be different from those reported from herds in Europe, where different management practices and pathogen profiles were observed.

The present study highlights the importance of SCC for monitoring udder health across the dry period. The use of individual quarter SCC (by means of cow side tests such as electronic cell counters) before and after the dry period has been increasingly available and used on farms with the aim of making individual cow decisions. However, care should be taken when extrapolating the results of this study using SCC information obtained from composite milk samples. Composite milk SCC is expected to be less sensitive as a diagnostic test 
to detect IMI as compared with quarter SCC, and this could be a more important issue, particularly in herds with few cows infected with contagious pathogens. Results of our study suggest that the use of previous SCC information can be useful to identify quarters with increased risk of developing mastitis in early lactation. Further research to evaluate the effectiveness of interventions that aim to decrease the incidence of mastitis in this group of quarters is warranted.

\section{CONCLUSIONS}

In summary, quarters with $\mathrm{SCC} \geq 200,000$ cells/mL across the dry period (estimated chronically infected based on SCC) had increased risk of developing clinical mastitis (for cases which occurred between 2 and 120 DIM) as compared with quarters with SCC $<200,000$ cells/mL across the dry period (estimated uninfected based on SCC). Parity and the occurrence of clinical mastitis during the previous lactation were also significant risk factors for the development of clinical mastitis in the first 120 DIM and should be considered when using SCC information to make individual cow management decisions.

\section{ACKNOWLEDGMENTS}

We are thankful to Sandra L. Trower, Jerry Guenther, and all the collaborators from the University of Wisconsin's Dairy Research Center, whose participation was essential for the execution of this study.

\section{REFERENCES}

Barkema, H. W., Y. H. Schukken, T. J. G. M. Lam, D. T. Galligan, M. L. Beiboer, and A. Brand. 1997. Estimation of interdependence among quarters of the bovine udder with subclinical mastitis and implications for analysis. J. Dairy Sci. 80:1592-1599.

Bradley, A. J., and M. J. Green. 2000. A study of the incidence and significance of intramammary enterobacterial infections acquired during the dry period. J. Dairy Sci. 83:1957-1965.

Cook, N. B., T. B. Bennett, K. M. Emery, and K. V. Nordland. 2002 Monitoring nonlactating cow intramammary infection dynamics using DHI somatic cell count data. J. Dairy Sci. 85:1119-1126.

Cook, N. B., D. A. Pionek, and P. Sharp. 2005. An assessment of the benefits of Orbeseal ${ }^{\oplus}$ when used in combination with dry cow antibiotic therapy in three commercial dairy herds. Bovine Pract. 39:83-94.

Dingwell, R. T., T. F. Duffield, K. E. Leslie, G. P. Keefe, L. DesCoteaux, D. F. Kelton, K. D. Lissemore, Y. H. Schukken, P. Dick, and R. Bagg. 2002. The efficacy of intramammary tilmicosin at drying-off, and other risk factors for the prevention of new intramammary infections during the dry period. J. Dairy Sci. 85:3250-3259.

Dingwell, R. T., D. F. Kelton, and K. E. Leslie. 2003. Management of the dry cow in control of peripartum disease and mastitis. Vet. Clin. North Am. Food Anim. Pract. 19:235-265.

Dingwell, R. T., K. E. Leslie, Y. H. Schukken, J. M. Sargeant, L. L. Timms, T. F. Duffield, G. P. Keefe, D. F. Kelton, K. D. Lissemore, and J. Conklin. 2004. Association of cow and quarter-level factors at drying-off with new intramammary infection during the dry period. Prev. Vet. Med. 63:75-89.
Dohoo, I. R., and K. E. Leslie. 1991. Evaluation of changes in somatic cell counts as indicators of new intramammary infections. Prev. Vet. Med. 10:225-237.

Godden, S., P. Rapnicki, S. Stewart, J. Fetrow, A. Johnson, R. Bey, and R. Farnsworth. 2003. Effectiveness of internal teat seal in the prevention of new intramammary infections during the dry and early-lactation periods in dairy cows when used with a dry cow intramammary antibiotic. J. Dairy Sci. 86:3899-3911.

Green, M. J., A. J. Bradley, G. F. Medley, and W. J. Browne. 2007. Cow, farm, and management factors during the dry period that determine the rate of clinical mastitis after calving. J. Dairy Sci. 90:3764-3776.

Green, M. J., L. E. Green, A. J. Bradley, P. R. Burton, Y. H. Schukken, and G. F. Medley. 2005. Prevalence and associations between bacterial isolates from dry mammary glands of dairy cows. Vet. Rec. 156:71-77.

Green, M. J., L. E. Green, G. F. Medley, Y. H. Schukken, and A. J. Bradley. 2002. Influence of dry period bacterial intramammary infection on clinical mastitis in dairy cows. J. Dairy Sci. 85:25892599.

Hoe, F. G. H., and P. L. Ruegg. 2005. Relationship between antimicrobial susceptibility of clinical mastitis pathogens and treatment outcome in cows. J. Am. Vet. Med. Assoc. 227:1461-1468.

Hogan, J. S., K. L. Smith, K. H. Hoblet, P. S. Schoenberger, D. A. Todhunter, W. D. Hueston, D. E. Pritchard, G. L. Bowman, L. E. Heider, B. L. Brockett, and H. R. Conrad. 1989. Field survey of clinical mastitis in low somatic cell count herds. J. Dairy Sci. $72: 1547-1556$

Laevens, H., H. Deluyker, Y. H. Schukken, L. De Meulemeester, R. Vandermeersch, E. De Muelenaere, and A. De Kruif. 1997. Influence of parity and stage of lactation on the somatic cell count in bacteriologically negative dairy cows . J. Dairy Sci. 80:32193226

Littell, R. C., G. A. Milliken, W. W. Stroup, R. D. Wolfinger, and O. Schabenberger. 2006. SAS for Mixed Models. 2nd ed. SAS Inst. Inc., Cary, NC.

Makovec, J. A., and P. L. Ruegg. 2003. Results of milk samples submitted for microbiological examination in Wisconsin from 1994 to 2001. J. Dairy Sci. 86:3466-3472.

National Mastitis Council. 1999. Laboratory Handbook on Bovine Mastitis. Natl. Mastitis Counc., Madison, WI

Neave, F. K., F. H. Dodd, and E. Henriques. 1950. Udder infections in the dry period. J. Dairy Res. 17:37-49.

Oliver, S. P. 1988. Frequency of isolation of environmental mastitiscausing pathogens and incidence of new intramammary infection during the non-lactating period. Am. J. Vet. Res. 49:1789-1793.

Oliver, S. P., and B. A. Mitchell. 1983. Susceptibility of bovine mammary gland to infections during the dry period. J. Dairy Sci 66:1162-1166.

Pagano, M., and K. Gauvreau. 2000. Principles of Biostatistics. Duxbury Press, Belmont, CA.

Ruegg, P. L. 2003. Investigation of mastitis problems on farms. Vet Clin. North Am. Food Anim. Pract. 19:47-73.

Sanford, C. J., G. P. Keefe, I. R. Dohoo, K. E. Leslie, R. T. Dingwell, L. DesCoteaux, and H. W. Barkema. 2006. Efficacy of using an internal teat sealer to prevent new intramammary infections in non-lactating dairy cattle. J. Am. Vet. Med. Assoc. 228:15651573.

SAS Institute. 2008. SAS/STAT User's Guide. Version 9.2, SAS Inst Inc., Cary, NC.

Seymour, E. H., G. M. Jones, and M. L. McGilliard. 1989. Effectiveness of intramammary antibiotic therapy based on somatic cell count. J. Dairy Sci. 72:1057-1062.

Shook, G. E. 1993. Genetic improvement of mastitis through selection on somatic cell count. Vet. Clin. North Am. Food Anim. Pract. 9:563-581.

Wilson, D. J., R. N. Gonzalez, and H. Das. 1997. Bovine mastitis pathogens in New York and Pennsylvania: Prevalence and effects on somatic cell count and milk production. J. Dairy Sci. 1997:2592-2598. 